Winter 2011

\title{
The Rule of Law Through Its Economies of Appearances: The Making of the African Warlord
}

Kamari Maxine Clarke

Yale University

Follow this and additional works at: https://www.repository.law.indiana.edu/ijgls

Part of the International Law Commons

\section{Recommended Citation}

Clarke, Kamari Maxine (2011) "The Rule of Law Through Its Economies of Appearances: The Making of the African Warlord," Indiana Journal of Global Legal Studies: Vol. 18 : Iss. 1 , Article 2.

Available at: https://www.repository.law.indiana.edu/ijgls/vol18/iss1/2

This Symposium is brought to you for free and open access by the Law School Journals at Digital Repository @ Maurer Law. It has been accepted for inclusion in Indiana Journal of Global Legal Studies by an authorized editor of Digital Repository @ Maurer Law. For more information, please contact rvaughan@indiana.edu.

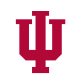

JEROME HALL LAW LIBRARY

INDIANA UNIVERSITY

Maurer School of Law
Blooming ton 


\title{
The Rule of Law Through Its Economies of Appearances: The Making of the African Warlord
}

\author{
KAMARI MAXINE CLARKE*
}

\begin{abstract}
The global reach of international law is now becoming relevant to the micromanagement of daily life. In postcolonial African states, everyday actions and their meanings are being opened up by the expansion of national jurisdiction into international jurisdiction. In relation to these changing technologies of managing shifting regimes of power, this article explores the ways that the spectacle of the rule of law is linked to the spectacle of capitalism. By examining the workings of victim and witness testimonies in the Special Court of Sierra Leone, I examine the ways that spectacles of law and articulations of suffering displace the realities of root causes of violence and the ways that these spectacles parse criminal responsibility. From rebel leaders spreading violence to the plunder of natural resources to child soldiers at once both victims and perpetrators, I detail the discursive crafting of the "African warlord" and the consequent specter of the victim by showing how law and justice are anchored in processes and concepts that often mask their normative underpinnings. Through its focus on victims' justice and not on the consumerism that fuels production, the Special Court of Sierra Leone serves not only as the author of new legal tenets of criminal responsibility, but also as a key mechanism of power through which the law obscures the conditions that affect its making. As such, like other spectacles of power, the law is able to make its labor invisible, while displacing human action and replacing it with spectacular performances
\end{abstract}

* M. Kamari Clarke is a professor of Anthropology and International and Area Studies at Yale University. She is the Chair of the Yale Council on African Studies and is a collaborative partner of the distinguished Leadership Enterprise for African Development (LEAD). I would like thank the following people for their contributions to this article: Jesse Shipley, Nadia McLennon, Callaine McLennon, Lieba Faier, Ariana Hernandez-Reguant, Tina Palivos, Caitlin Kerr, Jean Comaroff, Achille Mbembe, Anne Allison, Ian Baucom, and Barney Bate.

Indiana Journal of Global Legal Studies Vol. 18 \#1 (Winter 2011)

(C) Indiana University Maurer School of Law 
that affirm the rule of law that gains its force. It obscures its making not just through the staging and performances of rites, but also through the narrative strategies that consolidate an affective regime of suffering within which contemporary humanitarianism gains its power.

\section{INTRODUCTION}

Today, international tribunals have become mechanisms for "one of the most radical types of politicization:" one that produces a visual domain for the global consumption of rule of law spectacles. ${ }^{1}$ The unfolding regime of international criminal justice represents a terrain within which the supranational domain is brought into being in mostly national contexts through decisions on how to name crimes and determinations of who is responsible for the consequent violence (and thus punishable), and on what terms. ${ }^{2}$ But the supranational tribunal is an innovation in the contemporary present. In thinking about its attempts to consolidate power, we need to think about how power works through spectacle. A range of scholars have addressed the question of spectacle in different ways-from Plato on knowledge and its representation, ${ }^{3}$ to the literature on the spectacle as theatre and artifice, ${ }^{4}$ to writings on the spectacle of the state, ${ }^{5}$ or the postcolonial state and the banality of power. ${ }^{6}$ These studies have all been concerned with the ways that power is actualized in everyday spectacles. For instance, in The King's Two Bodies, Ernst Kantorowicz examined spectacles of governance by focusing on how jurists created the

1. Kamari Maxine Clarke, Fictions of Justice: The International Criminal Court and the Challenge of Legal Pluralism in Sub-Saharan Africa 94 (2009) [hereinafter CLARKE, FICTIONS].

2. See Mahmood Mamdani, The Politics of Naming: Genocide, Civil War, Insurgency, LONDON REV. BOOKS, Mar. 8, 2007, at 1, 5-8 (discussing the debate over classification of events in Darfur as genocide, investigating the words used to describe the situation, and arguing that, in the case of Darfur, "[i]t seems that genocide has become a label to be stuck on your own worst enemy, a perverse version of the Nobel Prize, part of a rhetorical arsenal that helps you vilify your adversaries while ensuring impunity for your allies.")

3. See TheaETETUS BY PLATO (Benjamin Jowett trans., 2006).

4. See generally JUDITH BUTLER, BODIES THAT MATTER: ON THE DISCURSIVE LIMITS OF "SeX" (1993); Michel Foucault, Discipline and Punsh: The BIRTH OF THE PRISON (1977); MarIlyn IVy, Discourses of the VANISHING: Modernity, PHANTASM, JaPAN (1995); Rosalind MORRIS, NEW WORLDS From FraGMENTS: Film, ETHNOGRAPHY AND THE REPRESENTATION OF NORTHWEST COAST CULTURES (1994).

5. See generally Clifford GeERTz, NEgARA: The ThEater STAte IN NineteENTH Century Bali (1981); ERnst H. Kantorowicz, The KInG's Two Bodies: A STUdY IN Mediaeval Political Theology (1957); Michael taussig, The Magic of the state (1997).

6. See generally ACHILL MBEMBE, ON THE POSTCOLONY (2001). 
seemingly mystical power of the king. ${ }^{7}$ Michael Taussig's The Magic of the State responded by considering how, through its representation, the state becomes inverted wholes of materialized artifices. ${ }^{8}$ In the domain of the legal spectacle, a large and growing literature on the "show trial," as it has been called, has developed over the past decade. For instance, as a way to understand the performativity of juridical rights to actualize power, Jean and John Comaroff have explored questions that range from crime, the law, and its extranational management ${ }^{9}$ to trials as media spectacles. ${ }^{10}$ In the world of international tribunals, scholars of law see show trials as potentially altering norms of behavior through the staging of hierarchies and the performance of rites. ${ }^{11}$ Yet this scholarship has fallen short of demonstrating how international trials are tied to political economies of violence that undergird these realities. In demonstrating the ways that international courts gain their political power through their affective power, I detail the way that root economic causes are displaced and a new politics of suffering is deployed in the name of humanitarianism.

In early August 2010, celebrity supermodel Naomi Campbell appeared as a witness before the Special Court for Sierra Leone (SCSL) held at the International Criminal Court (ICC) in The Hague. The news coverage was widespread and consistent-in 1997, Charles Taylor, the former Liberian President, allegedly gave Campbell a gift of "blood diamonds." Campbell's testimony was seen as potentially critical to the prosecution's case in establishing the timing of Taylor's possession of diamonds from Sierra Leone. Thus, the SCSL, the legal body charged

7. KANTOROWICZ, supra note 5.

8. TAUSSIG, supra note 5.

9. See generally John L. Comaroff \& Jean Comaroff, Law and Disorder in the Postcolony: An Introduction, in LAW AND DISORDER IN THE POSTCOLONY 1 (Jean Comaroff \& John L. Comaroff eds., 2006) [hereinafter Comaroff, Law and Disorder]; John L. Comaroff \& Jean Comaroff, Criminal Justice, Cultural Justice: The Limits of Liberalism and the Pragmatics of Difference in the New South Africa, 31 AM. ETHNOLOGIST 188, 189 (2004) (discussing "the challenge to the state and to the one law of the nation posed by cultural practices deemed 'dangerous"' in South Africa).

10. See generally Jean and John Comaroff, Criminal Obsessions, After Foucault: Postcoloniality, Policing, and the Metaphysics of Disorder, 30 CRITICAL INQUIRY 800 (2004) (investigating South Africa's preoccupation with the mediated representation of law and order).

11. See generally Martti Koskenniemi, Between Impunity and Show Trials, 6 Max PlanCK Y.B. U.N. L. 1 (2002); Jeremy Peterson, Unpacking Show Trials: Situating the Trial of Saddam Hussein, 48 HARV. INT'L L.J. 257 (2007). 
with overseeing Taylor's case, issued a subpoena for Campbell (as well as a number of her colleagues) to appear before the Court.

The prosecution argued that Taylor exchanged blood diamonds for weapons, arming Sierra Leonean rebels (members of the Revolutionary United Front (RUF)) and enabling them to undertake brutal attacks against innocent civilians. The defense maintained that Taylor, as the sitting president of Liberia at the time, was not connected to the atrocities committed by the rebels. In the end, the Campbell-Taylor story attracted popular attention to the trial and exemplified a range of stereotypes about "African warlords" and their worldly exploits, as well as a troubling distance between those who kill and those whose consumption feeds the cycle of profit pursued by those who kill. ${ }^{12}$ What remained uncovered by the press was the politics of those supply chain linkages. Although the case has been presented as focusing on Charles Taylor's criminal responsibility, at the heart of Campbell's testimony was the link between diamonds possibly illicitly procured and their legal consumption on the global market. This link highlights the relevance of the supply chain for mass atrocities-from violent killing fields to Hollywood celebrities and young brides-and the power of the capitalist imagination to transform meanings of value. The recipients of diamond gifts and the consumers who purchase them without regard for their origins are the unintentional enablers of violence, operating within what Anna Tsing has called the "economy of appearances"-a term she used to describe the dramatization of dreams that attracts investors. ${ }^{13}$ In other words, the appearance of a successful profit-making enterprise must be created to convince potential investors to provide financial capital for an investment-oriented venture or simply stated-"profit must be imagined before it can be extracted." 14

Tsing argues that economic performance and dramatic performance are linked to draw in an investment frenzy, as evidenced by the advent of Indonesian mining products, such as the Bre-X minerals and gold. "The more spectacular the conjuring [of a possible return on investments], the more possible an investment frenzy." 15 In the case of blood diamonds, it is the dramatization of the triumph of the rule of law through the spectacle of "the court," and "the perpetrators" that it houses that is central to the economy of appearances. International courts, such as the SCSL, are part of a set of performances staged to

12. See Philippe Le Billon, The Political Ecology of War: Natural Resources and Armed Conflicts, 20 POL. GEOGRAPHY 561 (2001).

13. Anna Tsing, Inside the Economy of Appearances, 12 PUB. CULTURE 115, 118 (2000).

14. Id.

15. Id. 
dramatize the authority of the rule of law. ${ }^{16}$ Judicial activities produce the regulating power of extranational institutions through which the spectacle of the warlord is key to providing the moral legitimacy of its work. ${ }^{17}$ The investors are those who invest their money and time to raise donor funds that contribute to the work of courts. Importantly, the SCSL is funded through voluntary contributions from governments from over forty countries, including Canada, Nigeria, the Netherlands, the United Kingdom, and the United States. ${ }^{18}$ This makes it the first international criminal tribunal with that record.

The moral authority of the court is also important in its economy of appearances through pursuit of "justice for victims." 19 Charles Taylor, the alleged warlord, has been assigned responsibility for commanding the murder and rape of men and women and boys and girls, as well as the plundering of African resources. The trial provided a spectacle of two sides at war for public consumption-the prosecution and the defense attorneys struggling over evidentiary questions linking one man, acting as a commander, to the atrocities of many. Even more importantly, and the focus of this article, is the way that the new international justice regime draws its moral power not only from the assignment of guilt to the warlord, but also from the victims of warlimbless amputees, raped girls with babies, drug-addicted child soldiers-who are all part of our collective imagination and whose presence is critical to supporting the spectacularization of international justice. The more spectacular the conjuring of the victim, the more urgent the call to support-morally, fiscally, legally-the rule of law. Yet, despite the assumption that it is a moral force alone that victims provide such tribunals, the paradox is that the figure of the victim sensationalizes the power of international trials and produces an economy of appearances in the realm of international adjudication. In this case, the victim is consolidated into the demonization of the African

16. See Le Billon, supra note 12, at 579.

17. See Robert Cryer, Prosecuting International Crimes: Selectivity and the INTERNATIONAL CRIMINAL LAW REGIME 131-32 (2005).

18. The Special Court Funding Mechanism, SPECIAL CourT of SierRA LeONE, http://www.sc-sl.org/ (last visited Feb. 16, 2011); Agreement Between the United Nations and the Government of Sierra Leone on the Establishment of a Special Court for Sierra Leone, U.N.-Sierra Leone, Jan. 16, 2002, 2178 U.N.T.S. 137 [hereinafter Agreement between U.N. and Sierra Leone].

19. See generally Tim Allen, Trial Justice: The InTernational CRIMinal CourT AND THE LORD'S RESISTANCE ARMY (2006); Raquel Aldana-Pindell, In Vindication of Justiciable Victims' Rights to Truth and Justice for State-Sponsored Crimes, 35 VAND. J. TRANSNAT'L L. 1399 (2002) (arguing in support of victim-focused prosecution); M. Cherif Bassiouni, International Recognition of Victims' Rights, 6 HUM. RTS. L. REV. 203 (2006) (expounding on the victim's rights jurisprudence and the courts that create it). 
perpetrator, a tyrant figure whose actions alone are represented as legally responsible for the decimation of local populations and are cast against the backdrop of the resource-rich and endemically violent "Africa" of the international imagination. Through the systematic elision of the root causes propelling violence, international criminal law finds a concrete "Other": a singular perpetrator-a commander directing mass violence, a warlord-whose agency can be severed only through external judiciaries, and whose acts of violence are recontextualized within a new political and moral economy based on victims' justice. ${ }^{20}$

The reality of the politicization of the figure of the African warlord is what makes Naomi Campbell's testimony before the court so compelling. Campbell represents the best of popular culture and the cycle of consumer complicity and provides a foil for unraveling the role of contemporary capitalism in the cycle of criminal responsibility. The reality of consumer power-the power to buy without guilt, to enable without scrutiny, to exist without popular recognition-not the warlord, is actually what is the most fascinating because it is a specter within society-an apparition that operates without explicit causality. ${ }^{21}$ It exists in an economy of appearances that focuses on the alleged warlord and not the enabling cycles of production and consumption that sustain war in the first place.

As addressed below, one of the things that the law also does well is bury the normative political apparatus through which legal norms are constructed. Thus an economy of appearances that features the warlord writ large, rather than the cycle of consumption that feeds the commodity chain, represents a construct whose social context is obscured by its attention to perpetrators in the name of victims everywhere. By examining the ways that law and justice are anchored in processes and concepts that often mask their normative underpinnings, this article explores the way that "law obscures the conditions that affect its making." 22 In so doing, it has the power to

20. See Aldana-Pindell, supra note 19 , at 1449.

21. See generally IAN Baucom, Specters of the ATlantic: Finance Capital, SLAVERY, AND THE PHILOSOPHY OF HISTORY 121 (2005) (offering that specter explains "uncanny and reiterative temporality"); JACQUES DERRIDA, SPECTERS OF MARX: THE STATE OF THE DEBT, THE WORK OF MOURNING, AND THE NEW INTERNational 3-5 (Peggy Kamuf trans., 1994) (defining specter as something that defies final empirical definition).

22. ClaRKE, FICTIONS, supra note 1 , at $\mathbf{1 7}$ (setting forth a similar argument that "[b]y examining the ways that law and justice are anchored in processes and concepts that often erase their normative underpinnings, this book explores that way that law, whether funneled through secular or religious mechanisms, obscures the conditions of its making"); see also OBIORA CHINEDU OKAFOR, RE-DEFINING LEGITIMATE STATEHOOD: INTERNATIONAL LAW AND STATE FRAGMENTATION IN AFRICA 104-05 (2000) (discussing African states' use of law to justify violent measures suppressing conquered peoples); MAKAU MUTUA, HUMAN 
make its labor invisible, while displacing human action and replacing it with spectacular performances. These spectacles reinforce the apparent power of the rule of law to affirm guilt or innocence and to individualize the violence of many and redirect it onto one individual. In the end, these spectacles work together with spectacular capitalism to produce an economy of appearances, that is, the way economies work through different spectacles to camouflage particular economic processes.

In the court transcripts below, the force of law is made real through the figure of the victim-a victim to be saved by the rule of law, a victim around whom collective guilt is made visible and reassigned to those seen as bearing the most responsibility for mass atrocity. African victims are central to the processes of international intervention, but not to the prescribed resolutions. Rather, the figure of the victim exists as a necessary precondition for imagining the legitimacy of the international reach of the SCSL. The imagery with which this figure collaborates is that of the third-world sufferer-the indigent individual, the defenseless child soldier forced to bear arms, the raped or violated concubine, the (African, Christian, Muslim, Jewish) refugee, or the internally displaced. African victimhood is crucial for constructing a moral obligation to punish the perpetrator in charge. Moreover, as a consequence of this focus on the perpetrator, the cycles of commodity chains are rendered insignificant. The possible ellipsis is the oftenviolent processes of producing what I refer to elsewhere as "a fiction of justice"-the creation and codification of a regime of truth that concerns itself with only some crimes and that celebrates the achievement of punishment and its symbolic potential to deter future crimes, rather than addressing some of the contests at the heart of violent struggles. ${ }^{23}$ The tribunal has used these newly emergent subject forms ("child soldier," "victim," "perpetrator," and "warlord") to transmute spaces for recuperating the violation of the victim into domains for the legitimacy of international adjudication. This recuperation, like highlighting the actions of insurgents, relocates agency from the state to inter- or supranational agents who, in sub-Saharan African contexts, set new terms for the management of violence.

The global reach of international law is thus becoming relevant to the micromanagement of daily life. In postcolonial African states, everyday actions and their meanings are being opened up by the

Rights: A POLITICAL AND CULTURAL CRITIQUe 41, 56-64 (2002) (discussing the constitutionalist approach to human rights, which sees "human rights norms [arising] out of the liberal tradition, and their application [achieving] a type of a constitutional system").

23. See ClaRke, FICTIONS, supra note 1, at $20-23$ (using the victims to narrativize past crimes "to incite various types of justice though a range of means"). 
expansion of national jurisdiction into international jurisdiction. In the case of this trial, Taylor has been indicted on a range of charges for commanding the murder, violent rape, and mutilation of hundreds of civilians. Taylor is also said to have supported and financed Foda Sankoh's rebel group, RUF, with the goal of destabilizing Sierra Leone in order to monopolize access to its diamond resources. His arrest on March 29, 2006, in Nigeria and his transfer to the SCSL in The Hague mark the power of international law to enact extradition, as well as to apply command responsibility internationally. ${ }^{24}$

In what follows, I outline the history of the rise and application of individual criminal responsibility in relation to the development of the SCSL. I then outline the related production of the African warlord-in this case Charles Taylor and his victimization of child soldiers-as a way to demonstrate how, like the spectacle that produced the Naomi Campbell debacle before the court but buried the political economy of consumerism, the duality of "victims" and "saviors" are constructed. In the final section, I examine the creation of the narratives of justice by examining the ways that subjects are made through particular practices of narrativization.

\section{The MaKing of the RULE of LAW SPECTACle: CoMmand RESPONSIBILITY}

One of the leading questions preoccupying studies that address the rise in international justice institutions, especially in the Global South, is how to make sense of the shift from truth and reconciliation commissions $^{25}$ to international tribunals. Another question is how to understand the shift in the assignment of guilt from lower level violators to commanders who are assigned individual criminal responsibility managed by international bodies. ${ }^{26}$ In relation to these changing technologies of managing shifting regimes of sovereign power, I am concerned with the changing notion of the social, that is, extant notions of subjectivity as they relate to the ways in which these regimes parse criminal responsibility-the rebel leaders spreading violence to

24. See Prosecutor v. Charles Ghankay Taylor, SPECIAL COURT OF SIERRE LEONE, http:/www.sc-sl.org/CASES/ProsecutorvsCharlesTaylor/tabid/107/Default.aspx (last visited Mar. 23, 2011) [hereinafter Taylor Case].

25. Jonathan Allen, Balancing Justice and Social Unity: Political Theory and the Idea of a Truth and Reconciliation Commission, 49 U. TORONTO L.J. 315 (1999); Boaventura De Sousa Santos, Law and Community: The Changing Nature of State Power in Late Capitalism, 8 INT'L J. SOC. L. 379, 386-87 (1980).

26. Jean-François Bayart, Stephen Eluis \& BÉatrice Hibou, The Criminalization OF THE STATE IN AFRICA 13-18 (Stephen Ellis trans., 1999). 
plunder natural resources, the consumers enabling violence, and the child soldiers at once both victims and perpetrators. In this regard, determining the conditions for victimhood and guilt can be quite difficult, especially when child soldiers are a part of the terrain of violence.

In the ten civil wars fought on the African continent in the past twenty years, a significant amount of the killing was committed by child soldiers-children trained to kill on command. Children are a particularly problematic category of criminals for such international courts because they are seen by some not only as perpetrators of murder, but also as victims operating under hierarchies of adult authority and needing rescue by the international justice community. When the latter leads to the absolution of criminal responsibility for children under international law, responsibility is reassigned to other offenders-African adults acting as rebel leaders and high-ranking commanders. $^{27}$ But in order to create the conditions for this reassignment of guilt, contemporary international legal institutions such as the ICC28 and the SCSL have operationalized command responsibility. ${ }^{29}$

Command responsibility represents a critical move toward the individualization of criminal responsibility. Through its popularization, command responsibility produces a social narrative about vicarious liability, which is common in many contexts across legal systems. But in international criminal contexts, it does not displace responsibility for lower-ranking individuals who also committed crimes and are being tried in lower courts. Rather, it merely coexists with them, promoting a narrative in which leaders are internationally held responsible for the violence enacted by those who serve them. In this regard, a new tenet of criminal law has emerged, redistributing accountability and redefining those who bear the responsibility for inflicting suffering, such as commanders. This initiative has implications both for the international management and assignment of responsibility for war crimes, and for the moral economies within which such initiatives are pursued.

There have been two critical moments in the twentieth century when comparable shifts in the management of criminal responsibility

27. It is worth noting that children-even those over age fifteen-are not, in fact, under the ICC's jurisdiction: "The Court shall have no jurisdiction over any person who was under the age of 18 at the time of the alleged commission of a crime." Rome Statute of the International Criminal Court art. 26, July 1, 2002, 2187 U.N.T.S. 90.

28. Bassiouni, supra note 19 , at 230.

29. William A. SchaBas, AN InTROduction to the INTERnational Criminal Court 83-85 (2001); Chris Allen, Warfare, Endemic Violence \& State Collapse in Africa, 26 REV. AFR. POL. ECON. 367, 371.72 (1999) (highlighting the organization of armed groups and their commanders). 
took place. The first was the major war trials held in Nuremberg and Tokyo after World War II. These trials addressed the principle of individual criminal responsibility for particular violations of international law applicable in armed conflicts. ${ }^{30}$ The second moment occurred with the adoption of the four Geneva Conventions on August $12,1949,31$ which established a specific framework for the prevention and punishment of grave crimes, and for the protection of war victims. ${ }^{32}$ However, today and over the past twenty years, the majority of armed conflicts involve civil wars in the Global South, in places such as Cambodia, Iraq, Sri Lanka, and other countries throughout subSaharan Africa, including Somalia, Rwanda, Sierra Leone, Liberia, Uganda, the Sudan, and the Democratic Republic of Congo (DRC)..$^{33}$ Many of the hostilities in Africa involve struggles to control the plunder of natural resources and are buttressed by a thriving underground military economy. ${ }^{34}$ Through such conflicts, the twentieth and early twenty-first centuries have witnessed the widespread militarization of everyday life, including the production of childhood killing fields.

This state of affairs began at "the close of the Cold War [when] a growing arms trade began to fuel African conflict zones in which rebel groups were vying for regional power." 35 Throughout the 1990s, in regions such as Sierra Leone, the Ivory Coast, the DRC, Rwanda, and Uganda, conflict resolution found little international support, despite obvious connections to global trade circuits, resulting in extreme disparities. In some sub-Saharan African countries, large segments of the population remained external to health services and wealth acquisition, ${ }^{36}$ while a small number remained at the center of new nodes

30. Richard Overy, The Nuremberg Trials: International Law in the Making, in FROM Nuremberg to the Hague: The Future of InTernational Criminal Justice 1, 2 (Phillipe Sands ed., 2003); Susan Twist, Rethinking Retrospective Criminality in the Context of War Crimes Trials, 27 LIVERPOOL L. REV. 31, 39 (2006).

31. The four Geneva Conventions and their agreements are as follows: Geneva Convention for the Amelioration of the Condition of the Wounded and Sick in Armed Forces in the Field, Aug. 12, 1949, 6 U.S.T. 3114, 75 U.N.T.S. 31; Geneva Convention for the Amelioration of the Condition of the Wounded and Sick, and Shipwrecked Members of Armed Forces at Sea, Aug. 12, 1949, 6 U.S.T. 3217, 75 U.N.T.S. 85; Geneva Convention Relative to the Treatment of Prisoners of War, Aug. 12, 1949, 6 U.S.T. 3316, 75 U.N.T.S. 135; Geneva Convention Relative to the Protection of Civilian Persons in Time of War, Aug. 12, 1949, 6 U.S.T. 3516, 75 U.N.T.S. 287.

32. STEVEN R. RATNER \& Jason S. ABRAMS, ACCOUNTABILITY FOR Human Rights ATROCITIES IN INTERNATIONAL LAW: BEYOND THE NUREMBERG LEGACY 82 (2d ed. 2001).

33. Henrik Urdal, People v. Malthus: Population Pressure, Environmental Degradation, and Armed Conflict Revisited, 42 J. PEACE RES. 417, 418 (2005).

34. Allen, supra note 25, at 371. See generally Billon, supra note 12.

35. ClaARE, FICTIONS, supra note 1 , at 45.

36. Comaroff, Law and Disorder, supra note 9, at 9-10. 
of power. With power exercised by means ranging from the enforcement of licit and illicit regulatory mechanisms that protect persons and property, to the control of economic speculation and investment, to resource control through military and political forms of brokering, violence and widespread death were not far behind. ${ }^{37}$

Experiencing ten civil wars in the past two decades-many rooted in mineral resource management, ethnic strife, and religious politics-the African continent is now a key site for the encroachment of a range of international courts and tribunals presented as the new solution to Africa's resource wars. Further, the signing of international treaties is increasingly becoming economically linked to democratic restructuring mandates. African states, in increasing numbers, have signed and ratified treaties such as the Rome Statute for the ICC. These shifts actually lead to the weakening of states' capacities to protect their borders, manage their populations, and control their markets and currencies, ${ }^{38}$ even as regional competitors strengthen their attempts to consolidate power for resource control. Indeed, multiple brokersincluding postcolonial state actors in Africa and elsewhere-are vying to control the terms that constitute the basis for justice. In response, various ad hoc tribunals have been crafted with the goal of stopping various nonstate paramilitary actions that result in widespread violence. Their mantras_-"no crimes against humanity should go unpunished" and "impunity must be stopped"-have come to constitute the tribunals' moral foundations.

In Sierra Leone, on Africa's west coast, another mechanism of international justice is under way-adjudication by the SCSL. The SCSL is a hybrid international court located in Freetown, Sierra Leone, that deals with investigations of the conflict that occurred in Sierra Leone from 1991 to $2002 .{ }^{39}$ During this period, extreme acts of violence were inflicted on civilians by rebel groups known as the RUF and the Armed Forces Revolutionary Council (AFRC). Widespread violent acts by these groups included murder, mutilation, amputation, torture, rape, abduction, and the conscription and use of child soldiers. In 2000, the United Nations intervened and, with the participation of the Sierra Leonean government, established the SCSL on January 16, 2002.40 As

37. Id.

38. Thomas Blom Hansen \& Finn Stepputat, Introduction, in SOVEREIGN BodIES: Cimizens, Migrants, and STATEs in the Postcolonial World 1, 32 (Thomas Blom Hansen \& Finn Stepputat eds., 2005).

39. Though the SCSL is based in Freetown, the trial for Charles Taylor is being heard at the International Criminal Court in The Hague. Taylor Case, supra note 24.

40. Agreement between U.N. and Sierra Leone, supra note 18. Furthermore, U.N. Security Council Resolution 1315 of August 14, 2000, requested "the Secretary-General to negotiate an agreement with the Government of Sierra Leone to create an independent 
an adjudicatory institution, the SCSL's mandate is to prosecute persons who bear the greatest responsibility for serious crimes committed since November 30 , 1996. It represents yet another international presence established to end impunity. The SCSL functions as a new adjudicatory mechanism for human rights abuses committed during the Sierra Leone armed conflict, in which the nation's governmental leaders were implicated in the commission of violent actions of rebel groups.

The SCSL is seen as a human rights body "with teeth,"-that is, a body with the ability to prosecute crimes. Today, there are four crimes under the subject matter jurisdiction of the Court: these are violations of Article 3 common to the Geneva Conventions and of Additional Protocol II (war crimes), crimes against humanity, other serious violations of international humanitarian law, and crimes under Sierra Leonean law. ${ }^{41}$ As of October 2010, ten individuals have been indicted on charges of committing crimes against humanity, war crimes, and other violations of international humanitarian law. ${ }^{42}$ Only nine individuals were convicted and are currently in the custody of the SCSL: Issa Hassan Sesay, Augustine Gbao, Morris Kallon, Moinina Fofana, Allieu Kondewa, Johnny Paul Koroma, 43 Alex Tamba Brima, Ibrahim Bazzy Kamara, and Santigie Borbor Kanu. ${ }^{44}$ The trial against Charles Taylor was extended on February 8, 2011, thus a judgment has yet to be reached. ${ }^{45}$ The trials have been placed into three groups:46 the Civil

special court consistent with this resolution." S.C. Res. 1315, ๆ 14, U.N. Doc. S/RES/1315 (Aug. 14, 2000).

41. The Trial Chamber has the power to impose a lifetime prison sentence upon any nonjuvenile offender. Statute of the Special Court for Sierra Leone arts. 2-5, 19, Jan. 16, 2002,2178 U.N.T.S. 138.

42. For more information on some of these cases, see Case 14: The Prosecutor vs. Fofana and Kondewa (CDF Case), SPECIAL COURT FOR SIERRA LEONE, http://www.scsl.org/CASES/ProsecutorvsFofanaandKondewaCDFCase/tabid/104/Default.aspx (last visited Mar. 9, 2011); Case 15: The Prosecutor vs. Sesay, Kallo and Gbao (RUF Case), SPECIAL COURT FOR SIERRA LEONE, http://www.sc-sl.org/CASES/ProsecutorvsSesay KallonandGbaoRUFCase/tabid/105/Default.aspx (last visited Mar. 9, 2011).

43. Johnny Paul Koroma was reported to have been killed in June 2003. As of September 2008, the Special Court has not been provided with definitive evidence of his death, and the indictment against him stands. See Prosecutor v. Koroma, Case No. SCSL2003-03-I, Indictment (Mar. 7, 2003), http://www.sc-sl.org/scs//Indictments/SCSL-03-03PT\%20Koroma\%20Indictment.pdf.

44. There were initially thirteen indictments made; however, the indictments against Foday Saybana Sankoh (RUF), Sam Bockarie (RUF) and Sam Hinga Norman were withdrawn upon the deaths of these individuals.

45. See Alpha Sesay, Déjà Vu at the Charles Taylor Trial, TrLal of Charles TaYlor (Feb. 16, 2011), http://www.charlestaylortrial.org/2011/02/16/deja-vu-at-the-charles-taylortrial/.

46. Taylor's trial stands alone and is being tried in one of the ICC court rooms in The Hague. 
Defence Forces trial for Fofana and Kondewa started on June 3, 2004, and concluded, after appeals, on May 28, 2008; the RUF trial for Kallon, Gbao, and Sesay began on July 5, 2004, and concluded on October 26, 2008; and the AFRC trial for Brima, Kamara, and Kanu began on March 7, 2005, and concluded, following appeals, on February 22, $2008 .{ }^{47}$ In the end, Kallon, Gbao, and Sesay were found guilty of war crimes and crimes against humanity. Kallon and Sesay were each found guilty on sixteen counts and Gbao was found guilty on fourteen counts.

Charles Taylor's trial represents spectacular performances in which a new language of responsibility and a new moral economy of victimhood-the rationale for just intervention-are articulated and displayed. In their testimonies, witnesses were asked by the prosecutor to map the chain of association of the perpetrators of violence and thus to highlight the leaders of the organization. The violence in Sierra Leone, Liberia, and the Ivory Coast from the early 1990s represents an example of inquiries into the chain of command. Testimony when the perpetrator is also the victim, as with the child soldier, illustrates in the most explicit terms the horror of the specter occurring alongside the performance of justice as triumph. In these contexts, shadows of violence-the violence of poverty, the violence of inequality, the violence of death-exist alongside the dramatic performance of international justice. Though such testimonies are necessary qualifiers for the establishment of an injustice, they are not in and of themselves sufficient to enable the address and arrest of root causes.

In the next section, I demonstrate that this is because of a process that Susan Harding calls "narrative encapsulation," that is, a mechanism of narrativization in which one story is "subordinated to and reframed by the terms of another." 48 In this case, what could be encapsulated as a story about political economy becomes subordinate to a story about African warlords and helping victims through adjudication. ${ }^{49}$ By showing how the process of narrative encapsulation works, I show how the rule of law works through the economy of

47. Case 16: The Prosecutor vs. Brima, Kamara, and Kanu (AFRC Case), SPECLAL COURT FOR SIERRA LEONE, http://www.sc-sl.org/CASES/ProsecutorvsBrimaKamaraand KanuAFRCCase/tabid/106/Default.aspx (last visited Mar. 23, 2011); Case 14: The Prosecutor us. Fofana and Kondewa (CDF Case), SPECIAl CourT for Sierra LeONe, http://www.sc-sl.org/CASES/ProsecutorvsFofanaandKondewaCDFCase/tabid/104/Default.aspx (last visited Mar. 23, 2011); Case 16: The Prosecutor us. Sesay, Kallon, and Gbao (RUF Case), SPECIAL COURT FOR SIERRA LEONE, http://www.sc-sl.org/CASES/ ProsecutorvsSesayKallonandGbaoRUFCase/tabid/105/Default.aspx (last visited Mar. 23, 2011).

48. Susan Friend Harding, The Book of Jerry Falwell: Fundamentalist LANGUAGE AND Politics 65 (2000).

49. See id. 
appearances. Here I trace particular witness transcripts from the SCSL hearings to outline the legal formation of the African warlord in relation to the making of the victim child soldier. Though I observed some of the Charles Taylor trial and also read many related transcripts over the course of my research, the next section focuses specifically on an excerpt from November 12, 2008, in which a witness, Augustine Mallah, testifies before the court. His testimony demonstrates the making of command responsibility and the workings of narrative encapsulation in which both victim (or witness) and perpetrator categories easily displace narratives about political economy at the root of the conflict.

\section{The MAKING Of THE Specter of The Victim Through the AFRICAN WARLORD}

In response to the SCSL prosecutor's questions, Augustine Mallah describes how he was enlisted into the war in Sierra Leone as a child soldier and later what the associated chain of linkage was to Taylor.

PROSECUTOR. How did it happen that you were captured?

AUGUSTINE MALLAH. Well, there was war in our village and so my family, that is my mother and my father and my sisters and many others were residing in the village, that is Jeoma. We were there and one morning we saw people from Liberia and they entered into the village, having guns with them, and they surrounded the village and they told all of us to go to the court barri and assemble there.

P. You said these people that came to your village with guns were from Liberia. How did you learn that they were from Liberia?

AM. That was what they told us and, besides that, even the way they spoke was different from the way Sierra Leoneans spoke so we knew that they were from Liberia.

P. You said that they told you they were from Liberia. What did they tell you?

AM. They told us that they had come from Liberia, that they were the ones who had brought the war, that Foday Sankoh had organised and he had told them to bring the war to Sierra Leone to come and liberate us from what 
we had been suffering from that he did not favour, so he had come to liberate us.

P. Did they tell you what group they belonged to?

AM. Yes. Some of them said they were RUF fighters from Liberia.

P. Did you learn the names of any of these people who came to your village?

AM. C Benjamin, SK Zoro Coin with Augustine Koroma who was the-he was the Sierra Leonean among them. Those are the names that I can recall now. There were many.

P. Mr Witness, when these people came into your village and took you to the barri, what happened at the barri?

AM. From the time we were all assembled they told us that-after they had spoken to us they said they had come to liberate us from the government that was in power and after they had spoken to us they took me and some of my sisters and other women who were in the village, together with men, and they took us out of the village and went with us.

P. When they were speaking to you at the barri, what language were they using, if you know?

AM. It was Liberian English.

P. Mr Witness, did you learn if there was any leader among the people who came to your village?

AM. Yes, ma'am.

P. Who was that?

AM. They said CO SK Zoro Coin.

P. How did you learn he was the leader?

AM. Well, they told us that they were the leaders and he was the commanding officer. 
P. You said they told you that they were the leaders and he was the commanding officer. What do you mean when you say they told you they were the leaders?

AM. Well, what they told us was that Foday Sankoh was the leader for the war that they had brought to Sierra Leone, but those who went to our village, they said he was their commanding officer, he was their commander.

P. You told the Court that after they had gathered you at the barri they took you and others away. How many people were taken away?

AM. Well, we were many. We were more than 50 , those of us who were taken out of the village.

$P$. And what was the gender of those who were taken away?

AM. Well, first the young ones they told us that they were going to take us to the base to be trained, together with some girls. There were some women who were captured. Those were young women. They took them to be their wives and that they were going to go with them to where they were.

P. Now the young ones they were taking for training, what was the gender of those people? Were they males, females, or both?

AM. Well, on that day it was only male that were taken to the base on that day.

$P$. What were the ages of the males that were taken for training?

AM. Well, some of them were $10,11,14,20$. For me, I was above 20 years.

P. You said that females were taken as wives. What were the ages of the females that were taken as wives?

AM. Well, they too-like one of my sisters, she was very young. She was about 7 to 8 . She was going to school. The other one was about 11 to 12 years old and the others 15,16 years, 18 years, most of them. 
P. Your sister that was young and going to school, the one that you said was 7 or 8 , did you ever see her again after that?

AM. Up to now we don't know where she is.

P. And the sister that was about 11 or 12 years old, did you ever see her again?

AM. Yes. ${ }^{50}$

Here we see an all-too-familiar witness statement, in this case by Augustine Mallah, narrating his capture. The line of questioning is directly concerned with the structure of leadership, attempting to determine the line of command as well as establishing the nature of the violations by those who committed crimes under the jurisdiction of the court. The next line of questioning attempts to determine the scope of the violations. His testimony exemplifies a typical narrative:

$P$. When you saw your sister again what, if anything, did she tell you?

AM. Yes. She told us that the very same people who went to the village, who captured all of us, she said one of them turned her into his wife. She was with him.

$P$. Now how was it that you were able to see your sister-this sister-again?

AM. Well, she was with the man who captured us, because the man was a Liberian according to what she told us, but at the time that the Sierra Leone Government pressurised the RUF fighters in Pujehun District, that was 1991, the first retreat into Liberia from Sierra Leone, she hid away from the man and went into the bush, together with her companions. They were there up to the time we came around the Soro Gbema area, Pujehun District. She heard that there were people in the towns, and people who were in the bush when they heard that they came out of the bush and so I met her in one of the villages. That was where I saw her. ${ }^{51}$

50. Prosecutor v. Taylor, Transcript, SCSL-2003-01-T, at 200056-60 (Special Court of Sierra Leone Nov. 12, 2008), available at http://www.sc-sl.org/LinkClick.aspx?fileticket= $\mathrm{zMQ1L6mPccE}=\&$ tabid $=160$.

51. Id. at 20061. 
Mallah then describes the making of child soldiers and the nature of the force used to ensure the success of that process. Here he describes a range of violations:

P. Mr Witness, as you were walking from your village being taken for training, did you try to escape?

AM. No, I did not attempt. I did not attempt escaping.

P. Why not?

AM. Because where they took us to, that is Moala, some of our brothers attempted to escape. When they were captured I saw them being killed and dumped into the river. From there they took us and put us into the vehicle, so I never thought of such a plan any more from that point to escape.

AM. When we entered Gisiwulo, they took us to a camp which they had constructed in the bush by the field. After they had taken down our names, from me where I was born and what was the name of my father and my mother's name and the year of my birth, after they had taken down all of those details they took me to that bush and they put me into the house and they told me that was where I was to be for the training. So, in the morning they called formation in the field. They said we were to go there for the training and all of us assembled there.

P. Mr Witness, who was it who was taking down this information, your name, your father's name, your place of birth, your date of birth? Who was doing that?

AM. It was Chico Mayer.

P. Chico Mayer, was this person a male or a female?

AM. A male. He was the training adjutant.

P. Mr Witness, did you learn how it was that Chico Mayer was there at that training base? 
AM. Yes, he himself told me that he was one of the Sierra Leonean soldiers who was assigned at the border-at the Liberian border. Initially when the rebels entered he was captured but, because they knew that he had some knowledge in the training and they wanted to train more people to join the RUF, he was encouraged and taken to the base to be there as the training adjutant.

P. You also said that after they had taken all of the details about you they put you in a house and told you that was where you would be for the training. This house, were you alone in that house, or were there other people in the house with you?

AM. We were many. We were many. It was one platoon. They said I was to go to the A Company. That was where the company base was. That was the hut for the company base. They said I was to be there. We were many. It was a big booth that was built in the bush.

P. How long were you at this training base for training?

AM. Almost two months.

P. During this two months, did you learn how it was that the other people in your house came to be there at the training base?

AM. Yes, all of us were there, just like the way I was there. Many of us were there and we were undergoing the same training.

P. While you were at the training base what type of training did you receive?

AM. Well, they taught me guerrilla training. I underwent the guerrilla training.

P. And what do you mean when you say guerrilla training?

AM. Guerrilla training, they said it was a different kind of training than the military because a guerrilla should go and fight against the government army and that a guerrilla is not a national army and if you are a guerrilla 
you are to live in the bush and you should do everything for yourself in the bush.

P. What sort of things did they teach you?

AM. They taught me how to fight against my enemy, how to fire arms, how to escape from the enemy.

$P$. What types of arms did they teach you to fire?

AM. They taught me how to fire AK-47 and they also told me how to fire RPG and I was taught how to fire GMG and I was taught how to fire AA, BZT, bazooka, many. ${ }^{52}$

Then in an attempt to determine the link between the RUF and Liberian commanders, like Charles Taylor, the prosecutor asked a line of questioning making distinctions between the Liberians doing the training in relation to the Sierra Leoneans:

P. And do you know what group or groups these training instructors belonged to?

AM. Yes, they were Liberians.

P. And do you know what group they belonged to?

AM. Yes, they said they were NPFL soldiers.

$P$. Now, you said you were in the house or in a house of a company and there were beaucoup people in the house with you. When you underwent this training can you tell the Court how many people were undergoing the training at Gisiwulo?

AM. We were more than 1,000 .

$P$. And what was the gender of these people who were undergoing this training?

AM. They were males, we were in our own camp, and there were females and they were in their own camp.

$P$. And the females, if you know, what kind of training were they receiving?

AM. They too-all of us were undergoing the same training. They were being taught how to fight, how to 
manoeuvre from the enemy, how to fire a gun. All of the trainings that we undertook, they too undertook the same.

P. What were the ages of the people being trained at Gisiwulo?

AM. Well, earlier on I told you that some were up to 10 years, some were 11,14 years, 18 years, 20, 22. That was it.

P. While you were at this camp for two months, did you ever refuse to take training?

AM. No, nobody would refuse. In that camp you would not refuse. Because even those who attempted to escape, who attempted to escape from the base, when they were captured they would bring them right in our presence and they would kill one or two of them just to set an example, so if somebody said you were not going to train, you refused being trained and that you were not sick, they will beat you until you will say, "Well, I will go onI will go on the training." They will punish you severely.

$P$. While you were at this camp did you have any visitors to the camp?

AM. Yes.

P. Who?

AM. Even Foday Sankoh, at a point in time he visited us there. Then some of the Liberian commanders used to come there and train us at times for an hour or two hours and they would return.

$P$. At the point in time that you were at this camp did you know who Foday Sankoh was?

AM. Yes, they used to tell us that the war that he had brought to Sierra Leone, that is those who captured us, and when we were being trained at the base they said their leader was Foday Sankoh.

P. You said some Liberian commanders would come to the camp. Do you remember the names of any of these commanders? 
AM. One Man One used to go there. CO Baday, used to go there. CO Mon Ami used to go there. Foday Sankoh himself went there. ${ }^{53}$

During the trial, the prosecution spent a significant amount of time determining how the RUF's guerilla army worked and how it was coordinated. Shortly after the questions about being enlisted, the prosecutor asked a range of questions about the coordination of power:

AM. Well, One Man One, what he told us at the base, he himself, while all of us were in the formation, he said the war that entered Pujehun District, that he was the commander for all of the fighters.

P. Did you learn what group he belonged to?

AM. Yes. He said he was an NPFL soldier.

P. Did you learn his nationality?

AM. Yes. He said he was a Gio man.

$P$. And from what country?

AM. He said Nimba County.

P. Did he tell you what country that is in?

AM. Yes. He said it was Liberia.

P. You mentioned CO Baday. Who was he?

AM. He too was a Gio man. According to CO Baday, he said One Man One was his elder brother.

P. And did he tell you what group he belonged to?

AM. Yes. He said he too was an NPFL soldier.

P. Did you learn what country he was from?

AM. Yes. He said he was from Liberia. ${ }^{54}$

The transcripts are full of details of the command chains, identities, names, spellings, and roles. Through the narration of a victim who is able to establish that violations had been committed against him, the

53. Id. at $20067-69$.

54. Id. at 20069 . 
prosecution then engaged in a line of interrogations about the chain of command:

P. You said that a person you called CO Mon Ami also visited the camp. Who was CO Mon Ami?

AM. Well, CO Mon Ami, according to him, he said all of them came from Liberia. He said they had fought the Liberian war, together with the NPFL, but that he was one of the Special Forces from Gambia . . . So, together with the Liberians, they were the ones who entered into Sierra Leone with the war. And that he was one of the training instructors who used to go and train us at the base.

P. Train you at what base?

AM. Gisiwulo base.

P. Did he explain to you what he meant when he said he was a Special Forces?

AM. Yes.

P. What did he tell you?

AM. He said they were the ones who trained together with Foday Sankoh, Charles Taylor. He said they trained together, all of them.

P. Now, just to be clear for the record, I would like to go back to something you said earlier when you were talking about what was done to people who tried to escape from the base. On my font it is page 20,13 to line 20. You said, "They would bring them right in our presence and they would kill one or two just to set an example." Who was it who brought them and killed one or two?

AM. It was the training instructors from Liberians. The Liberians who used to train us.

P. And you also said, "They will beat you until you will say, 'Well, I will go on. I will go on training." Who would beat you?

AM. The training instructors from Liberia. 
P. Mr Witness, what year was it that you concluded your training at Gisiwulo?

AM. It was in 1991.

P. After you had been captured and trained, were you told what group you were now a member of?

AM. They said-yes, they said I was a junior commando RUF fighter.

$P$. And after you were trained and became a member of the RUF, how long did you remain a member of the RUF?

AM. I was a member right throughout from 1991 right up to the end of the disarmament.

P. What year was it that the end of the disarmament occurred, in your experience?

AM. 2002.

P. Now, you mentioned that they told you you were a junior commando. Did they explain to you what they meant by junior commando?

AM. Yes.

P. What did they tell you?

AM. They said the RUF had three categories. One was the Special Forces; that is those who trained together with Foday Sankoh and Charles Taylor, they were the Special Forces. Those who were captured and trained in Liberia, they were referred to as the vanguards and they were the ones who trained us in Sierra Leone . . . .55

These hearings depict the particular creation of the child soldier for the purposes of transferring responsibility to another subject-what is referred to in legal circles as the "assignment of culpability." The shift from children as perpetrators to children as victims to be protected was made possible through the indictment of commanders, such as Charles Taylor, or Foday Sankoh, Slobodan Milosovic, and Saddam Hussein, in which the discourse of the rule of law is played out as a triumphant mechanism of justice. The assignment of culpability, codified in subsection a of Article 28 of the Rome Statute, imposes individual

55. Id. at 20070-74. 
responsibility on military commanders if they "either knew or, owing to the circumstances at the time, should have known that the forces were committing or about to commit such crimes." 56 Subsection 3 of Article 6 of the SCSL Statute lays out the "should have known" standard, 57 which imposes an affirmative duty to remain informed of the activities of subordinates:

The fact that any of the acts referred to in articles 2 to 4 of the present Statute was committed by a subordinate does not relieve his or her superior of criminal responsibility if he or she knew or had reason to know that the subordinate was about to commit such acts or had done so and the superior had failed to take the necessary and reasonable measures to prevent such acts or to punish the perpetrators thereof. ${ }^{58}$

This requirement is a point of contention with lawyers. ${ }^{59}$ Precedent for establishing the "knowledge" criterion has been based on two possible conditions. The first involves whether the commander "knew"; the second is based on whether the commander "had reason to know." The background for understanding whether a commander "knew" about the commission of violence refers to actual knowledge, which can be established either directly or indirectly through circumstantial evidence. But the meaning of "had reason to know" is often discussed in the case law in relation to whether a subordinate was about to commit crimes and the commander failed to take measures to prevent or punish such acts.

One of the formative influences for establishing principles of command responsibility in the SCSL Statute came from an ad hoc tribunal set up by the United Nations on May 25, 1993, to adjudicate

56. Rome Statute of the International Criminal Court art. 28, supra note 27.

57. Statute of the Special Court for Sierra Leone art. 6, supra note 41.

58. Id. art. 6(3).

59. The International Criminal Tribunal for the Former Yugoslavia (ICTY) interpreted the language of "had reason to know" under Article 7(3) of its Statute of the Tribunal as requiring the commander to have "had in his possession information of a nature, which at the least, would put him on notice of the risk of such offences by indicating the need for additional investigation in order to ascertain whether such crimes were committed or were about to be committed by his subordinates." Prosecutor v. Delalić, Case No. IT-96-21-A, Judgment, I 223 (Int'1 Crim. Trib. for the Former Yugoslavia, Feb. 20, 2001), www.icty.org/x/cases/mucic/acjug/en/cel-aj010220.pdf. Notably, the Trial Chamber commented that it made no findings on the present state of customary law, which may have changed following the adoption of the Rome Statute of the International Criminal Court in 2002. Id. ๆ 182. 
war crimes in the former Yugoslavia. The International Criminal Tribunal for the Former Yugoslavia (ICTY) first considered the scope of command responsibility in Prosecutor $v$. Delalic et al., also known as the Čelebići case. ${ }^{60}$ It reached an important conclusion on the knowledge standard, deciding that commanders have a duty to be "constantly informed of the way in which their subordinates carry out the tasks entrusted to them."61 In the SCSL, the principles of command responsibility dictated that commanders were responsible for taking the necessary measures to fulfill this obligation. In an attempt to fulfill this knowledge requirement, prosecutorial interests in command responsibility directed the structure of the proceedings in the Charles Taylor case.

As an anthropological inquiry, the process of classifying crime and responsibility in this way redirects attention toward the mechanisms through which the power of international law gains its force. In this case, the spectacle of law gains its force not just through the staging of the hierarchies and the performances of rites within the court, but also through the micropolitics of legal reasoning and the uses of narrative encapsulation to produce particular realities. Once command responsibility was legally established, prosecutors needed only to show that actual violence was inflicted on particular victims in order to demonstrate the commission of a crime. The result was the relegation of suffering and the violence the victims experienced, thus establishing their condition of victimhood. Witness narratives were narrowly tailored to explain chains of responsibility through which the prosecution could articulate a connection between child soldiers and Charles Taylor, thereby attributing responsibility to him for child-soldier violence against civilian and military populations. In this process of incorporation and display of responsibility, the court performed the role of author. Through its texts, transcripts, images, videos, legal procedures, and performances, the court institutionalizes victimhood in mediated ways that are also familiarly racialized as "African." The victim is then represented through an abhorrent, yet impotent sign of victimhood that haunts legal proceedings.

The explicit narratives of victim suffering-the discussions of loss and hunger, the conditions that caused them to kill in the first place, and the guaranteed consumer demand that enables these cycles-are taken as secondary. Instead, like a ghost, the details of the violations are negated, yet still exist as a specter of suffering. This ghostly presence established via the absence of the victim drives the perceived

60. Id. ๆข $223,236$.

61. Int'l Comm. of the Red Cross [ICRC], Commentary on the Additional Protocols of 8 June 1977 to the Geneva Conventions of 12 August 1949, I 3560 (1987). 
moral economy of judicial interventions in sub-Saharan Africa. Through the articulation of African victims as the basis for legitimate engagement, there is a necessary construction of the commanding perpetrator as a warlord-someone who operates above the law and whose impunity cannot be allowed to continue. In the quest to abrogate such practices, the rule of law is deployed strategically, through the invention and development of a new language of responsibility whose repercussions are never fully knowable. This is how narrative encapsulation works-it spectacularizes one reality by renarrativizing another.

The process of crafting the African warlord and the specter of the victim demonstrates how the SCSL served not only as the author of new legal tenets of criminal responsibility, but also as a key mechanism of power through which the violence of neoliberal moral values and economic practices spread. In an interview to African Press International on April 11, 2009, Stephen Rapp, a prosecutor for the SCSL, explained the rulings against Issa Sesay: "Most importantly they honor the victims who suffered because of the acts and decisions of these individuals. The judgment of the trial chamber has helped re-establish justice and the rule of law in Sierra Leone, without which lasting peace and development is not possible."62 However, the contemporary expansion of the rule of law movement and the rise of the defense of the "victim" reflect various powerful phenomena working in tension with each other. One such phenomenon involves the way that particular neoliberal moral values are gaining global traction through the efforts of governmental and nongovernmental institutions and organizations, which provide those who have been socially marginalized with spaces from which to make justice claims.

Another supplemental influence in the current international rule of law movement is the economic force of neoliberal capitalism. As one of many policy trajectories within which human exchange and value is shaped, this form of capitalist strategy has been widespread since the 1970 s, when it was imposed on a range of developing countries by powerful financial institutions such as the International Monetary Fund (IMF), the World Bank, and the Inter-American Development Bank. Neoliberal capitalism has had the effect of deemphasizing governmental and nongovernmental intervention in national economies and privileging instead free-market methods that liberate business operations. Informed by laissez-faire economics and working through

62. Sierra Leone: Rebel leaders get long jail sentences, AFRICAN PRESS INT'L (Apr. 11, 2009, 12:33 AM), http://africanpress.wordpress.com/2009/04/11/sierra-leone-rebel-leadersget-long-jail-sentences-his-lawyer-wayne-jordash-described-the-decision-as-the-mostunfair-result-of-a-trial-that-was-also-unfair-in-the-history-of-international-tribunal/. 
international institutions such as the World Trade Organization (WTO), the World Economic Forum, the International Convention on Labor (ITO), and various free-trade treaty agreements, as opposed to relying on direct government intervention to apply multilateral political pressure through labor politics and collective bargaining, neoliberalism has opened foreign markets to corporate colonization. In doing so, it has fostered restrictions of economic possibilities in other domains.

Critics have argued that the consequences of this program throughout sub-Saharan Africa and Latin America include unfair competition, the erosion of workers' rights, ${ }^{63}$ and the escalation of resource-related struggles that are often refracted through religious and ethnic conflicts. ${ }^{64}$ In postcolonial African states, neoliberal expansionism suggests a renewal of an earlier-told narrative: management policies around export-driven growth developed with the support of global institutions, including the World Bank, the IMF, and other lending institutions. The ongoing trend is one in which rich corporate interests supported by market democracies work alongside international organizations to shape new economic values and practices in the Global South. ${ }^{65}$ These new global economic alliances have made it increasingly difficult for postcolonial states to maintain economic independence and

63. See, e.g., Ugo MatTei \& Laura Nader, Plunder: When the Rule of LAW is ILLEGAL 4 (2008) (arguing that "foreign-imposed privatization laws that facilitate unconscionable bargains at the expense of the people are vehicles of plunder, not of legality"); Sandra T. Barnes, Global Flows: Terror, Oil, and Strategic Philanthrophy, AFR. STUD. REV., Sept. 2005, at 1, 1 (examining "the implications of [American] military and business initiatives for African nations and the reasons for lack of information about them"); see also Evelyne Huber \& Fred Solt, Successes and Failures of Neoliberalism, LATIN AM. RES. REV., no. 3, 2004 at 150 (analyzing the successes and failures of neoliberal reforms in Latin America in order to show that "slow and cautious economic reforms accompanied by [specific] social policy efforts ... and deliberate institution-building strategies" will more firmly establish "growth, stability, the reduction of poverty and inequality, and improvements of the human capital base" than will a standard set of neoliberal reforms).

64. See, e.g., Dena Montague, Stolen Goods: Coltan and Conflict in the Democratic Republic of Congo, SAIS REV., Winter-Spring 2002, at 103 (arguing that the war in the Democratic Republic of Congo is, in part, a result of international economic investment in rebel movements, which creates kleptocracy and corruption); Jesse Weaver Shipley, Introduction, 83 ANTHROPOLOGY Q. 472 (2010) (introducing articles from the issue, entitled "Ethics of Scale: Relocating Politics after Liberation," examining Jean Comaroff's book, BODY of POWER, SPIRIT OF RESISTANCE: THE CULTURE AND HisTORY OF A SOUTH AFRICAN PEOPLE (1985), and discussing history and culture in postliberation South Africa).

65. Deborah A. Thomas \& Kamari Maxine Clarke, Introduction: Globalization and the Transformations of Race, in GLOBALIZATION AND RACE: TRANSFORMATIONS IN THE Cultural Production of Blackness 1, 8 (Kamari Maxine Clarke \& Deborah Thomas eds., 2006). 
political autonomy, particularly in resource-rich areas. ${ }^{66}$ Instead, in subSaharan Africa, the response to the changing market has led to increasing paramilitary contests over resources, furthering militarization and sectarian violence. The consequences have been grave. While the economies of trade in ammunition and mineral resources have found buyers on the global market, they also produced killing fields in several African regions. ${ }^{67}$

In the final section, I discuss the consequences of the new spectacle of international trials in the consolidation of the image of the black African body. The African body is conceived as the body to be saved by humanitarian intervention in such a way that highlights the use of narrative encapsulations by silencing the political economy at play.

\section{HUMANITARIANISM AND THE MORAL ECONOMY OF INTERNATIONALISM}

As spectacles of suffering and narrativization, the truth and reconciliation commissions of the late twentieth and early twenty-first centuries tended to assign victims spaces for narrativizing devastation, 68 providing a symbolic possibility for a postviolence democratic transition. ${ }^{69}$ In South Africa, Rwanda, Sierra Leone, and Morocco, various forms of truth and reconciliation mechanisms allowed for the production of discourses on victimhood in which African victims found ways to narrativize their losses through new vernacular forms. These forms often incorporate discourses of loss articulated through global human rights narratives and the integration of particular indigenous sensibilities, religiosities, cultural styles, and moralities. In contrast, the SCSL's goal of ending the impunity of commanders highlights a new relationship with African subjects: one that deploys the figure of the African victim not for the production of compassion, forgiveness, or reconciliation, but for the propulsion of a mission of reassigning responsibility for grave and widespread crimes. At the heart of this reassignment of the perpetrator are not only contemporary politics of legitimacy, embedded in a morality of humanitarianism

66. See generally JAMEs Ferguson, Global Shadows: AFriCA IN THE NeOLIBERAL WORLD ORDER (2006) (collecting a series of the author's essays examining Africa's place in the world economy, and discussing the historical and social construct of what is considered "Africa").

67. See Slavoj Žižek, Against Human Rights, NEW LEFT REV., July-Aug. 2005, at 115, 123-24. See generally Slavoj Žižek, From Politics to Biopolitics . . . and Back, $103 \mathrm{~S}$. ATLANTIC Q. 501 (2004).

68. Richard A. Wilson, The Politics of Truth and Reconciliation in South AFRICA: LEgITIMIZING THE POST-APARTHEID STATE 109 (2001).

69. ERICA CaPLe James, Democratic InSECuRities: Violence, Trauma, AND INTERVENTION IN HAITI 88-89 (2010). 
highlighting a new moral sociality-in Africa, in particular-, but also a new set of legal and discursive practices in which narratives of humanitarian encapsulation are at play. These narratives provide the makings of a spectacle of the rule of law in which the individual criminal responsibility reassigned to Taylor reallocates not only the responsibility of hundreds of killers engaged in economic competition, but also the responsibility of those whose consumption feeds such cycles of production. ${ }^{70}$

The "humanitarian" gesture of "reaching out" for "Africa's benefit" is of course not new; it has precedents in the history of African colonialism and the neocolonial humanitarian and development projects. This reassignment has recast the management of responsibility for some of the worst forms of contemporary violence to be addressed within the life of the law. The underlying morality at play generates the moral fortitude that undergirds the liberal idea of the rights-endowed subject whose suffering is to be not only acknowledged but rewarded-now through international intervention and a kind of victim's justice. As in the case of Charles Taylor, the development of an institutional infrastructure for the victim-and the drive to protect that categorypropels this new moral economy of extranational intervention as the new workings of sovereignty. ${ }^{71}$ The benevolence of the new internationalism not only reveals some of the most tragic forms of victimhood, but also, through its mission and justice-seeking goals, sustains the spectacle of suffering. It is in this spectacle that cycles of narrative encapsulation continue to promote narratives central to the mission of legal institutions, rather than promote the re-articulation of economic narratives.

At the dawn of the rise of international courts, special focus on child soldiers and preoccupation with African indictments responded to and exacerbated stereotypes of Africa as politically fragile, legally inept, and economically volatile. The child-soldier identity serves, in many ways, as a metonym for childhood, and thus as a spectacle for international intervention. This paternalism heralds the incorporation of the rule of law into the continuing history of institutional protectionism, legal and constitutional intervention, and the management of African resources by colonial and humanitarian regimes. Through particular adjudicatory

70. See Mariella Pandolfi, Contract of Mutual (In)Difference: Governance and the Humanitarian Apparatus in Contemporary Albania and Kosovo, IND. J. Global LEGaL STUD., Winter 2003, at 369, 380-81 (2003) (discussing the "do something syndrome," which is governments' response to public concern about a crisis).

71. Partha Chatterjee, Empire and Nation Revisited: 50 Years After Bandung, 6 INTERAsIa CUlTURAL STUD. 487, 492 (2005) (recounting how global conditions fueled the protection of human rights and democratic values from despotic and authoritarian rulers). 
exclusions, such as the vanishing child soldier, narratives of suffering become secondary to the prosecution of those who are deemed responsible for crimes under investigation. These processes of ellipsis are already normative in state criminal trials. In both common law and canon law criminal cases, victims bear little influence except by way of offering witness testimony, despite the fact that the rise in power of international justice institutions is amassed through the claim to champion the cause of the violated. This claim has been broadcast through an acute deployment of the imagery of global victims-woman, African, child, black, brown, Muslim. In the case of sub-Saharan Africa, the body being defended (and subjugated) is particularly racialized-a black body whose histories of enslavement, war, famine, militarization, and economic failure continue to fuel a Western moral imperative of intervention. The specter of frailty haunts the display of international justice through the figure of the child soldier-a young body who, though possessing a complex subjectivity of perpetrator-victim, is split, abstracted, and recast as defenseless victim. This apparition is central to international authority, which cannot exist without it because the moral force of suffering legitimizes its claim. As such, it is more important than ever to understand the changing nature of the socialthe ways that contemporary law-making and justice-producing domains gain their power through a new "governmentality" whose power requires not only the rites staged through legal hierarchies and performances, but also the spectacle of suffering as the basis for justice.

Two hundred years after the British abolished their slave trade in 1807 , it is now the language of "humanitarianism" that embodies the international discourse around human entitlements to life. Through its charge to protect human rights, this mode of justice represents the possibility that victims everywhere, without regard for national citizenship alliances, are entitled to international inclusion and protection. This presumption of rights and protections is materializing alongside the expansion into international domains of the new biopolitics of the postcolonial state. The biopolitics of the postcolonial state are enabled by the erosion of state capacities to build a viable economy for citizens, to command and regulate access to resources in the domestic economy, ${ }^{72}$ and to build innovative judiciary mechanisms capable of incorporating indigenous cultural traditions through which to direct future polities. This new internationalized form of governance is subtler than earlier colonial forms, yet represents a more tragic set of

72. See Achille Mbembe, Necropolitics, 15 PUB. CULTURE 11, 33 (Libby Meintjes trans., 2003). 
realities because of the subtle ways that guilt and power are brought to bear on contemporary violence.

\section{CONCLUSION-SEEING TRIALS: BEYOND THE EMPIRICISM OF ADJUDICATION}

This analysis began by suggesting that underlying cycles of consumer demand exist alongside spectacles of war violence. It demonstrated that when victims or characters of perceived guilt are the focus, we fail to see the fields of analytic interaction within which they are operating. Likewise, we fail to see the conditions under which particular types of displacement were brought into being. These international trials are a new modality for articulating guilt and intervening through the language of humanitarianism. These trials contribute to the creation of victim-specter relationships and these relationships are diffused in the play of politics and the economy, creating more violence, which eventually leads to a trial, and so forth. In order for legal studies to be useful beyond doctrinal classifications and applications, we need to explore the forms of materiality, as well as phenomenological constellations of imagination, which simultaneously shape the spaces between grammars of violence-the core social realities that explain histories of violence-and the exclusions that haunt those histories. As I have shown, international institutions work through the law to craft "victims" and "perpetrators" (or, indeed, "victim-perpetrators") within the parameters of legal science. These individuals participate actively in such constructions, yielding new subjects through which humanitarianism is further legitimatized.

The international management of violence by tribunals intent on ending the impunity of state leaders has become a privileged solution to the familiar problem of state complicity in violence. Through a process of first destabilizing networks of violence through the arrest of highranking leaders and then attempting to vindicate victims through tribunalization, a new moral economy of justice has developed in which the international ascension of concerns for the protection of the victim exists by way of the reassignment of perpetrator guilt. In this new governmental context, the sign of Africa has come to symbolize the idea of childhood in the international humanitarian imagination. The child soldier represents the most oppressed and destitute aspects of humanity. ${ }^{73}$ It is through this context that international courts draw their moral fortitude, their force of law. By exploring the circulation and application of new "bodies of power" involved in the crafting of African

73. ClaRKE, FICTIONS, supra note 1 , at 115. 
subjects, I have reflected on the limits of and challenges to the liberal project of choreographing the management of life. It is here in the social life of liberalism, its technical production and ethical cultivation, that political contestations lie and that the site for rethinking new forms of African governmental bodies must dwell.

What we are witnessing, then, is a radical normalization of governance in which particular vernacular forms that once shaped the basis for life are measurable through public spectacles of the rule of law. These displays, narrativized as justice producing, hold power through the creation of a theater of justice. They represent the performance of justice through an economy of appearances that attempts to make loss and disenfranchisement bearable. The generative significance of such international, spectacular movements-in-the-making exists as a kind of self-deception with far-reaching consequences. Movements to establish judicial authority through the moral imperative to end impunity can never quite redress the horror of loss or evade the incessant reminder that the capture of a commander, or the deployment of command responsibility to reassign guilt, will not end violence. The sources of violence lie elsewhere; they lie in the banality of the everyday and its dramatic efforts to control the terms of life and the production of death. Underlying cycles of consumer demand also exist alongside spectacles of war violence, but these cycles are never the object of engagement by those concerned with the preservation of rights. Instead, it is political rights, not economic rights that undergird the contemporary rule of law movement.

Today's reality is that in certain African countries, economically, politically, and socially shaped forms of violence are increasingly managed in sites and markets outside the continent. The argument here is that the dramatic performances of justice-making mechanisms, the show trials, are arising elsewhere. These sites are central to making sense of the ways that the investment in the rule of law supports a growing industry of not only consumer goods tied to violence and the humanitarian bandwagon to "save Africa," but also the regime of ruleof-law making itself. The spectacular conjuring of the need for trials as the only objective way to achieve "justice" shapes the dramatization of the triumph of the rule of law central to a particular economy of appearances. ${ }^{74}$ But the reality is that these adjudicatory spheres of interactions are masked as inclusions in new international rule of law movements and involve moral intervention in the name of victims. These exclusions speak to the externalities of management that are increasingly becoming technocratic and linguistically specific, and

74. Tsing, supra note 3 , at 118 . 
around which adherents are expected to structure their speech, claims, criticisms, and aspirations. This performance, this theater, linked as it is to a profoundly uneven global political economy, actually undermines the capacity of institutional justice to ameliorate explicit forms of material violence at play. 